Available online: https://journals.researchsynergypress.com/index.php/ijebce/

International Journal of Entrepreneurship, Business and Creative Economy (IJEBCE)

ISSN 2775-3085 (Online) | 2775-3107 (Print)

Volume 1 Number 1 (2021): 66-73

\title{
Personal Financial Behavior in Surakarta Students
}

\author{
Ari Susanti ${ }^{1}$, Septiana Widiastuti ${ }^{1}$ \\ ${ }^{1}$ Sekolah Tinggi Ilmu Ekonomi Surakarta, Indonesia
}

\begin{abstract}
Personal financial literacy among students is still minimal attention. This study aims to examine financial literacy, financial attitude, and lifestyle towards student financial behavior. Students who became respondents were 730 populations and 88 samples. Respondents are STIE Surakarta students who study at night and, on average, have worked. The analysis used is multiple linear analysis with the SPSS version 21 analysis tool. This study indicates that financial literacy has no significant effect on financial behavior, while financial attitude and lifestyle variables significantly affect financial behavior.
\end{abstract}

Keywords: financial literacy, financial attitude, income, lifestyle, financial behavior

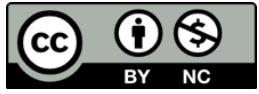

This is an open access article under the CC-BY-NC license.

\section{INTRODUCTION}

Personal finance for students is sometimes not a major concern because students depend on their income from their parents, living their lives without having short, medium, and long term goals. Even if it has been introduced from an early age or a young age, students should have thought about future plans to better prepare themselves to meet their needs and life goals. The most important element in personal financial management is financial literacy, where financial literacy can add to financial literacy, which shapes student behavior to be better prepared for their future. Good budgeting needs to be supported by good financial literacy knowledge and financial management. Students have not familiarized themselves with finance because financial behavior is still based on their desire.

Financial behavior has a good impact on allocating income and expenses according to needs, not wants. Research conducted by Herdjiono and Damanik (2016) states that Indonesia's consumptive behavior is not according to their ability in terms of income. According to Mien and Thao (2015) having good financial behavior is very important. Because it can form patterns in saving, investing, and anticipating budgets that can become a lot from time to time due to consumptive behavior and emotional decisions in the use of funds. In fact, people, especially young people who are still productive at work, must face financial problems and usually experience financial problems to not meet their unexpected daily needs.

Financial behavior has several elements that influence, as was done by Nur Fatima and Susanti (2018) that financial behavior is influenced by financial literacy. The ability to understand, know about financial management, and always practice it in everyday life into financial behavior is the definition of financial literacy. Financial literacy support will affect a person's ability to add 
insight to financial management and help make someone more confident and conscientious in the use of funds and decision making.

Financial behavior can also be seen in terms of financial attitude, according to research conducted by Herdjiono and Damanik (2016) saying that financial behavior is influenced by financial attitude. The existence of a financial attitude can affect the attitude in evaluating the use of finances.

Another influence on financial behavior can be seen from the lifestyle of a person who at this time pays more attention to wants than needs so that a lifestyle can have a good and bad impact on someone. According to research conducted by Delyana Rahmawany Pulungan, Murviana Koto, and Lena Syahfitri (2018), financial behavior is influenced by this lifestyle. According to Sumarwan, (2011), a person's lifestyle can change quickly according to taste and what he wants. A choice that must be balanced between income and expenses to adjust in running their life.

\section{LITERATURE REVIEW}

\section{Financial Literacy}

Financial literacy has a description of helping someone in making decisions and making various choices in financial behavior. Financial literacy can assist in financial management in making financial budgets both in and out of financial management. This financial behavior must be supported by consistency in the financial planning that has been made. Financial literacy helps in understanding the real value, which is the nominal value of money and the occurrence of inflation, so that financial literacy means understanding financial concepts that impact good and correct financial knowledge on the behavior of everyday life, especially in financial allocation.

The indicators used in this research are the preparation and planning of the budget to be received and issued, compliance and consistency in planning the expenditure budget that has been made, understanding the real and nominal value of money, and understanding inflation (Deasy Lestari Kusnandar, Dian Kurniawan, 2018).

\section{Financial Attitude}

According to Pankow (2003), Financial attitude is the ability to manage one's state of mind, income, and financial assessment. Financial attitude reflects attitudes that a person has about managing finances by forming a mindset, managing good and correct financial management methods, and allocating finances following what has been budgeted or planned. According to Furnham (1984), the financial attitude indicators are obsession, strength, effort, insufficiency, retention, and security.

\section{Lifestyle}

The lifestyle that a person has is called a lifestyle. A lifestyle is also a form of one's expression in carrying out various activities, opinions, and interests in forming self-image to improve society's social status (Kotler (2010). Lifestyle can also change according to one's taste, both tastes in fashion, food, socializing, and adapting to what happens in life changes. (Sumarwan, 2011). The indicators used in measuring lifestyle in this study, according to Peter and Olson (2000), are activities in the form of hobbies, vacations, work, interests in family, community, work, and opinions covering social, business and political issues. 


\section{Financial Behavior}

According to Kholilah and Iramani (2013), the ability to plan and manage daily income and expenses is inherent in a person called financial behavior. In addition, if someone can manage financial behavior, financial allocation based on needs can also be properly allocated, such as in the choice of consumption, bill payment, life needs, saving allocation, and how to go into debt. The indicators used in this research are consumption, cash flow management, saving and investment, and credit management.

\section{Hypothesis Development}

This study develops the following hypothesis results:

\section{The effect of financial literacy on financial behavior}

Nur Fatimah and Susanti (2018) "The Influence of Learning Financial Accounting, Financial Literacy, Income on Financial Behavior of Students at the Faculty of Economics, Muhammadiyah University Gresik", Nyoman Trisna Herawati (2015) in research "Contribution of Learning in Higher Education and Financial Literacy on Student Financial Behavior", Nur Fatimah Susanti (2018) "The Influence of Learning Financial Accounting, Financial Literacy and Income on Financial Behavior of Students of the Faculty of Economics, University of Muhamadiyah Gresik". This study states that financial literacy has a significant effect on financial behavior. Based on the research results above, the hypothesis can be taken as follows:

H1: Financial literacy has a significant effect on financial behavior.

\section{The effect of Financial Attitude on financial behavior}

Irine Herdjiono and Lady Angela Damanik (2016) in research "The Effect of Financial Attitude, Financial Attitude, Parental Income on Financial Management Bahavior", Nur Laili Isniawati and Nadia Asandimitra (2018) with research "The Influence of Demography, Financial Attitude, Locus of Control and Financial Self-Efficacy Against the Financial Management Behavior of the Surabaya Community". This study states that financial attitude has a significant effect on financial behavior. Based on the research above, the hypothesis can be taken as follows:

H2: Financial Attitude has a significant effect on financial behavior

\section{The effect of income on financial behavior}

Yusnia and Zubaedah (2017) in "The Influence of Income, Focus of Control and Financial Knowledge on Financial Behavior of SMEs in Cinere District", Irine Herdjiono and Lady Angela Damanik (2016) with research "The Effect of Financial Attitude, Financial Knowledge, Parential Income on Financial Management Behavior. ". This study shows that income has a significant effect on financial behavior. Based on the research results above, the hypothesis can be taken as follows:

H3: Income has a significant effect on financial behavior.

\section{The influence of lifestyle on financial behavior}

Deasy Lestary Kusnandar, Dian Kuurniawan in "Financial Literacy and Lifestyle of Housewives in Shaping Financial Behavior in Tasikmalaya City", Delyana Rahmawany Pulungan, Murviana Koto and Lena Syahfitri (2018) with research "The Effect of Hedonic Lifestyle and Emotional Intelligence 
on Financial Behavior. College student". This study shows the results that lifestyle affects financial behavior. Based on the research above, the hypothesis can be taken as follows:

H4: Lifestyle has a significant effect on financial behavior

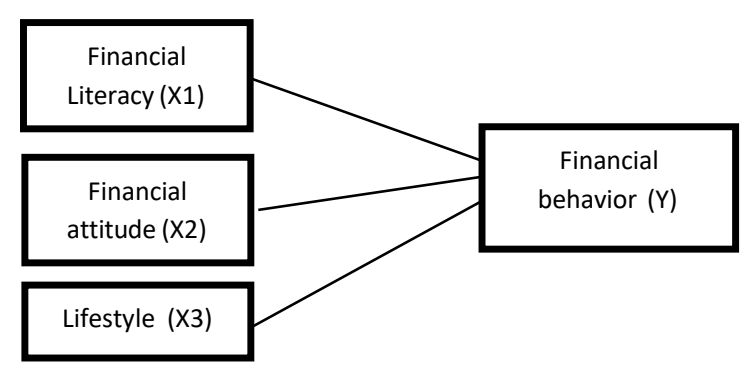

Figure 1: Research Framework

\section{RESEARCH METHOD}

The research method uses multiple linear regression data analysis using SPSS 21 in the data processing. The population in this study amounted to 730 respondents who were students. The population is calculated using the Slovin formula so that the sample obtained is 88 respondents. This study uses probability sampling techniques, which means taking samples by providing equal opportunities to all populations.

Table 1: Research Indicators

\begin{tabular}{|c|c|c|}
\hline No. & Variables & Indicator \\
\hline 1 & $\begin{array}{l}\text { Financial } \\
\text { Literacy }(\mathrm{X} 1)\end{array}$ & $\begin{array}{l}\text { 1. Preparation and planning of budgets to be received and issued, } \\
\text { 2. Compliance and consistency in planning the expenditure } \\
\text { budget that has been made, } \\
\text { 3. Understand real value } \\
\text { 4. Understand the nominal value of money, } \\
\text { 5. Understand about inflation } \\
\text { Source: Deasy Lestari Kusnandar, Dian Kurniawan (2018) }\end{array}$ \\
\hline 2 & $\begin{array}{l}\text { Financial } \\
\text { Attitude (X2) }\end{array}$ & $\begin{array}{l}\text { 1. } \\
\text { 2. Stression, } \\
\text { 3. Effort, } \\
\text { 4. Insufficiency, } \\
\text { 5. Retention and Security. } \\
\quad \text { Source: Furnham (1984) }\end{array}$ \\
\hline 3 & Lifestyle (X3) & $\begin{array}{ll}\text { 1. } & \text { Activities (work, hobbies, vacations) } \\
\text { 2. } & \text { Interests (family, work, community) } \\
\text { 3. } & \text { Opinion (social issues, political issues, business) } \\
& \text { Source: Peter and Olson (2000) }\end{array}$ \\
\hline
\end{tabular}


International Journal of Entrepreneurship, Business and Creative Economy (IJEBCE), Vol. 1 (1), 66-73

Personal Financial Behavior in Surakarta Students

Ari Susanti, Septiana Widiastuti

\begin{tabular}{lll}
\hline 4 & Y: Financial & 1. Consumptive \\
Behavior & 2. Cash flow management \\
& 3. Saving and Investing \\
& 4. Credit Management \\
& Source: Dew and Xiao (2011) \\
\hline
\end{tabular}

\section{FINDINGS AND DISCUSSION}

\section{Analysis Results}

The research data instrument results, which included the validity and reliability of the variables in this study, were valid and reliable. The assumption tests, which consist of normality, multicollinearity, heteroscedasticity, meet the requirements. Data processing results are as follows:

1. Normality Test

Table 2: Normality Test

\begin{tabular}{lc}
\hline \multicolumn{3}{c}{ Unstandardized Residual } \\
\hline $\mathrm{N}$ & 88 \\
Asymp Sig. (2-tailed) & 0,800 \\
\hline
\end{tabular}

Source: Primary data processed (2020)

The results of the normality test above show a significant value greater than 0.05 , so this research data is declared normal

2. Multicollinearity Test

Table 3. Multicollinearity Test Recapitulation

\begin{tabular}{lllc}
\hline \multicolumn{1}{c}{ Variable } & Tolerance & VIF & Results \\
\hline Financial Literacy (X1), & 0,687 & 1,466 & \\
Financial Attitude (X2), & 0,520 & 1,923 & No \\
Lifestyle (X3) & 0,578 & 1,729 & Multicollinearity \\
\hline
\end{tabular}

Source: Primary data processed (2020)

This study did not have multicollinearity. Tolerance values above 0.1 and VIF less than 10 , then all independent variables.

3. Heteroscedasticity Test

Table 4. Recapitulation of Heteroscedasticity Test

\begin{tabular}{lcc}
\hline \multicolumn{1}{c}{ Variable } & Sig & Results \\
\hline Financial Literacy (X1), & 0,748 & No \\
Financial Attitude (X2), & 0,887 & Heteroscedasticity \\
Lifestyle (X3) & 0,373 &
\end{tabular}

Source: Primary data processed (2020)

The following are the results of data processing based on the test equipment that has beenused. The results of multiple linear regression analysis of data processing are: 
International Journal of Entrepreneurship, Business and Creative Economy (IJEBCE), Vol. 1 (1), 66-73

Personal Financial Behavior in Surakarta Students

Ari Susanti, Septiana Widiastuti

Table 5. Multiple Linear Regression Results

\begin{tabular}{llcc}
\hline \multicolumn{1}{c}{ Variable } & Coefficient & t & Sig \\
\hline Constant & 3,874 & 2,401 & 0,019 \\
Financial Literacy (X1), & 0,108 & 1,473 & 0,144 \\
Financial Attitude (X2), & 0,250 & 2,699 & 0,008 \\
Lifestyle (X3) & 0,306 & 2,240 & 0,028 \\
\hline
\end{tabular}

Source: Primary data processed (2020)

The equation based on the results of multiple regression is

$\mathrm{Y}=3.874+0.108 \mathrm{X} 1+0.250 \mathrm{X} 2+0.306 \mathrm{X} 3$

a. The constant ( $\alpha$ ) 3,874 means that if Financial Literacy (X1), Financial Attitude (X2), and Lifestyle (X3) are zero (0), then Financial Behavior $(\mathrm{Y})$ is positive at 3,428.

b. The Financial Literacy Coefficient (X1) of 0.108 shows that if the Financial Literacy variable increases by 1 unit, then the variable $(\mathrm{Y})$, namely Financial Behavior, will increase by 0.108 , assuming the other variables are constant.

c. The Financial Attitude coefficient (X2) of 0.250 indicates that if the Financial Attitude variable increases by 1 unit, the variable (Y), namely Financial Behavior, will also increase by 0.250 assuming that the other variables are constant.

d. Lifestyle regression coefficient (X3) of 0.306 shows that if the Lifestyle variable increases by 1 unit, the variable (Y), namely Financial Behavior, will increase by 0.306 , assuming the other variables are constant.

4. T-test

Table 6. t-test results

\begin{tabular}{lllcll}
\hline \multicolumn{1}{c}{ Variable } & $\begin{array}{c}\mathrm{t} \\
\text {-value }\end{array}$ & t-table & Sig & $\mathrm{P}$ & Results \\
& & & & \\
\hline Financial Literacy (X1), & 1.097 & & 0.144 & & rejected \\
Financial Attitude (X2), & 3,271 & \multirow{2}{*}{1,988} & 0.008 & 0,05 & received \\
Lifestyle (X3) & 2,448 & & 0.028 & & received \\
\hline
\end{tabular}

Source: Primary data processed (2020)

Based on the above research results, it can be concluded that financial literacy has a significant effect. In contrast, financial attitude and lifestyle have a significant effect on financial behavior.

5. Coefficient of Determination

The coefficient of determination obtained is 0.359 , so the variable in this study is $35.9 \%$, and the remaining $64.1 \%$ is influenced by other variables not found in this study.

\section{DISCUSSION}

\section{Financial Literacy on Financial Behavior}

Financial behavior in this study is not influenced by financial literacy. It is because currently, students have not focused on future interests but only focused on existing funding needs. When there are funds held at that time, it is adjusted to the needs, and if there is a residual, it is used to save without thinking about proper financial literacy in determining financial planning for the future. This research is not in accordance with previous research conducted by Nur Fatimah and 
Susanti, (2018) and Herawati, (2015) but supports research conducted by Mega Dwi Rani Siahaan (2013), which states that financial behavior is not influenced by financial literacy.

\section{Financial Attitude to Financial Behavior}

This study's financial attitude shows an effect on financial behavior. Good financial skills can determine students in determining the right attitude or decision making. Students believe that they can adjust the financial attitude according to their funds and allocate it as needed, but if more funds can be used for their desires, it can increase student satisfaction. This research supports what has been done by Rizkiawati and Asandimitra (2018), that financial behavior is supported by financial attitude.

\section{Lifestyle on Financial Behavior}

Lifestyle influences financial behavior in this study, this is because students have personalities that are still easily influenced by interactions and the environment or the community around them. Usually as self-expression in financial behavior and manifesting their lifestyle. These results support research conducted by previous researchers by Koto and Syahfitri (2018) that financial behavior is influenced by lifestyle.

\section{CONCLUSION}

The conclusion that can be drawn from this study is that financial literacy does not affect financial behavior, while financial attitude and lifestyle affect financial literacy.

\section{LIMITATION \& FURTHER RESEARCH}

Suggestions that can be given in this study are that financial literacy is very important, so students should have started implementing good financial management. They should start to plan for the future by having short, medium and long-term goals. In addition to financial literacy, determining the right financial attitude is essential for students to avoid taking the wrong steps. Students in this research are mainly Millenials, so it cannot be denied that they follow a lifestyle based on desire, not need. Thus, financial literacy needs to be supported, which can change their lifestyle to be more supportive to the priority and just follow a lifestyle to not deviate in achieving goals and making decisions. Future research is expected to conduct caring research with income, finance, and financial management.

\section{REFERENCES}

Dew, Jeffery, Xiao Jing Jian, (2011), “The Financial Management Behavior Scale, Development and Validation, Journal of Financial Counselling and Planing", Vol. 22, hal. 43-59

Fatimah, Nur dan Susanti, (2018), "Pengaruh Pembelajaran Akuntansi Keuangan, Literasi Keuangan Dan Pendapatan Terhadap Perilaku Keuangan Mahasiswa Fakultas Ekonomi Universitas Muhammadiyah Gresik", Jurnal Pendidikan Akuntansi, Vol. 6, No. 1, hal. 48-57

Furnham, A., (1984), Many Sides of the Coin: The Psychology Of Money Usage, Personality and Individual Difference, 5: 501-509

Herawati, N.T., (2015), "Kontribusi Pembelajaran di Perguruan Tinggi dan Literasi Keuangan Terhadap Perilaku Keuangan Mahasiswa", Jurnal Pendidikan dan Pengajaran, Jilid 48, No., 13, hal. 60-70

Herdjiono, Irine dan Lady Angela Damanik, (2016), "Pengaruh Financial Attitude, Financial Knowladge, Parential Income Terhadap Financial Management Behavior", Jurnal Manajemen 
Teori dan Terapan, Tahun 9, No. 3

Herdjiono dan Damanik, (2016) dalam jurnal "Pengaruh Financial Attitude, Financial Knowladge, Parential Income Terhadap Financial Management Behavior

Ida dan Chintia Yohana Dwinta, (2010), "Pengaruh Locus of Control, Financial Knowladge dan Income Terhadap Financial Management Behavior", Jurnal Bisnis dan Akuntansi, Vol. 12, No. 3, hal. 131-144

J.Paul Peter \& jerry c. Olson (2000). Consumer Behavior Perilaku Konsumen. 2nd. ed. 4 Jakarta: .Penerbit Erlangga.

Kholilah, Naila Al dan Iramani, Rr. 2013, "Study Financial Management Behavior Pada Masyarakat Surabaya" Journal of Business and Banking Vol. 3, No. 1

Kotler, Philip and Amstrong, Gary, (2010), "Principles of Marketing, 13th Edition, New Jersey: Pearson Education, Inc, Publishing as Pretice Hall.

Kusnandar, Deasy Lestary dan Dian Kurniawan, (2018), "Literasi Keuangan Dan Gaya Hidup Ibu Rumah Tangga Dalam Membentuk Perilaku Keuangan Keluarga Di Kota Tasikmalaya", Prosiding Seminar Nasional dan Call of Paper Sustainable Competitive Advantage (SCA)

Mega Dwi Rani Siahaan, (2013), "Pengaruh Literasi Keuangan Terhadap Perilaku Keuangan Pada Mahasiswa Perguruan Tinggi Di Surabaya", Sekolah Tinggi Ilmu Ekonomi Perbanas Surabaya, (2013).

Mien Nguyen Thi Ngoc, Thao Thran Puong, (2015), Factor Affeting Personal Financial Management Behavior: Evidance from Vietnam Proceedings of the Second Asia

Nur Laili Rizkiawati, Nadia Asandimitra, (2018), "Pengaruh Demografi, Financial Knowladge, Financial Attitude, Locus of Control dan Financial Self-Efficacy Terhadap Financial Management Behavior Masyarakat Surabaya", Jurnal Ilmu Manajemen, Vol.6, No.3, Jurusan Manajemen Fakultas Ekonomi Universitas Negri Surabaya, (2018).

Pulungan, Delyana Rahmawati; Murviana Koto dan Lena Syahfitri, (2018), "Pengaruh Gaya Hidup Hedonis dan Kecerdasan Emosional Terhadap Perilaku Keuangan Mahasiswa", Prosiding Seminar Nasional Royal (SENAR),

Sumarwan, Ujang. 2011. Perilaku Konsumen: Teori dan Penerapannya dalam Pemasaran. Bogor: Ghalia Indonesia 